\title{
Determinants of Life Insurance Demand, Consumer Perspective - A Case Study of Ayeduase-Kumasi Community, Ghana
}

\section{Eric Effah Sarkodie ${ }^{1 *}$ and Hadrat M Yusif ${ }^{2}$}

${ }^{1}$ Department of Accounting Studies Education, College of Technology Education, University of Education, Kumasi, Winneba, Ghana

${ }^{2}$ Departments of Economics, College of Arts and Social Sciences, Kwame Nkrumah University of Science and Technology, Kumasi, Ghana

\begin{abstract}
This study finds out the determinants of life insurance demand in the Ayeduase-Kumasi community from the perspective of consumers. The study adopted Logistic regression modeling technique with 256 cross section observations. Income, higher education, number of dependents, employment by someone else and better perception about insurance firms improved the chances of taking life insurance. Age however, has negative relationship with the odds of taking life insurance. Number of dependents was statistically significant at $1 \%$. Age and Type of employment were both significant at $5 \%$ while's income and education level were significant at $10 \%$. Overall the Chi-Square showed that the model was statistically significant at less than 0.001 . This study had similar results to previous studies and deviates as well. Çelik and Kayali found a positive relationship between income and odds of taking insurance and that was not different from the results of this study. Contrary to Çelik and Kayali, higher education influences positively the odds of taking life insurance. Moreover, segmenting customers into different groups by using the type of employment as basis of segmentation could help insurance firms to prescribe policies that customers may patronize.
\end{abstract}

Keywords: Financial; Inflation; Insurance; Income; Wealth

\section{Introduction}

Insurance is a tool by which a small number are compensated out of funds (premium payment) collected from plenteous. Insurance company pays back for financial uses arising out of occurrence of insured evidence. Insurance is protecting against uncertainties. It provides financial restart for sufferers insured within policy of insurance. Insurance essentially, is an arrangement where the losses experienced by few are extended over several who are exposed to similar risks. Insurance is a protection against financial loss arising on the happening of an unexpected event. Insurance companies collect premium to provide security for the purpose. As loss is paid out of the premium collected from the insuring public and the insurance companies act as trustees to the amount collected (RANI, 2007).

The financial sector in Ghana over the years has significantly improved. This has helped in the growth of the service sector (Budget of Ghana, 2013). Life insurance market of transition economies had experienced a rapid growth over the last decade, indicating the increased importance of this sector as a financial intermediary [1]. The insurance traditions of the Ghanaian society is significantly less mature compared to the western developed countries, where the life insurance business, for instance, substantially increased its importance as a financial intermediary over the last 40 years and became one of the leading sources of investment in the capital market [1].

A key decision the individuals or families take is whether to buy life insurance or not. The reason behind considering such a decision is to protect against possible loss of income [2]. Life insurance provides individuals and the economy as a whole with a number of important financial services. In the face of escalating urbanization, mobility of the population, and formalization of economic relationships between individuals, families, and communities, life insurance has taken increasing significance as a way for individuals and families to manage income risk. Also, life insurance products encourage long-term savings and the re-investment of substantial sums in private and public sector projects.

In spite of the increasing importance that life insurance has in managing income risk, facilitating savings, and providing term finance, factors that determine its demand are not totally unveiled. A number of authors have alerted series of socio-economic and institutional factors that determinant life insurance demand. Inadequate data samples and variables on the other hand, have impeded the fullness of their study. This paper improves on the existing literature by using cross section data with stretched out sample size and variables.

\section{Literature Review}

Rani (2007) used probit regression modeling technique with 172 sample households on determinants of demand for insurance in Sulur Special Panchayat, Coimbatore District, India. From the analysis it was found that most of the respondents clearly explained that for their savings only they have demanded the insurance policies. In case of non-insurer, lack of income is one of the important economic factors for this non-demanding of insurance policies. Further, from the probit regression analysis, it was inferred that age, income and value of property have emerged significantly as determinants of demand for insurance. It was therefore concluded that the demand for insurance is not the purpose of risk aversion and savings. But people want to enjoy maximum benefit by paying minimum premium during their lifetime.

Nesterova [1], on determinants of demand for life insurance: evidence from selected Commonwealth of Independent States and Central and Eastern European countries using panel data analysis techniques for 14 countries over the period 1996-2006, find that countries with higher life expectancy at birth, income level, old

*Corresponding author: Eric Effah Sarkodie, University of Education, College of Technology Education, Department of Accounting Studies Education, Kumasi, Ghana, Tel: +233246810974; E-mail: effahsarkodie@yahoo.com

Received July 14, 2015; Accepted July 24, 2015; Published July 31, 2015

Citation: Sarkodie EE, Yusif HM (2015) Determinants of Life Insurance Demand, Consumer Perspective - A Case Study of Ayeduase-Kumasi Community, Ghana Bus Eco J 6: 170. doi:10.4172/2151-6219.1000170

Copyright: $\odot 2015$ Sarkodie EE, et al. This is an open-access article distributed under the terms of the Creative Commons Attribution License, which permits unrestricted use, distribution, and reproduction in any medium, provided the original author and source are credited. 
dependency ratio and countries (members of the European Union) have higher levels of life insurance consumption, while financial development indicator, inflation and real interest rate reduce the demand for life insurance across countries.

Beck and Webb (The World Bank, 1818 H St., N.W., Washington, D.C. 20433.) [3]. On determinants of life insurance consumption across countries using a cross-sectional sample of 63 countries averaged over 1980-96 found that educational attainment, banking sector development, and inflation are the most robust predictors of life insurance consumption, while income is only a weak predictor. The results on educational attainment and inflation were confirmed in 23 countries over the period 1960-96. The results strengthen the case for promoting price stability, financial sector reform, and an efficient education system if life insurance and its many benefits are to be fully realized in an economy.

Hammond [4] makes a study on the impact of economic and demographic factors of demand for life insurance by using regression analysis. They find that income, net worth holdings, stage in the life cycle, education, occupation significantly affect life insurance consumption.

Neumann [5] investigates the impact of inflation on life insurance consumption by using time series regression for the period of 19461964. However, other explanatory variables such as income, number of marriages, births and urban households are used to prevent spurious correlation. As a result, it is found that inflation has no significant effect on life insurance consumption.

Berekson [6] analyzes the impact of age, marital status, number of children financially responsible, gross income, birth order among siblings and parent's divorced on life insurance consumption by using regression analysis in 1969. They find that while age, number of children and birth order variables have significant effects on demand for life insurance, income is not significant for one survey and significant for another.

Fortune [7] studies the determinants of life insurance consumption by using multiple regression analysis for the period between 1964 and 1971. As a result of multiple regression analysis, non-human wealth held, wages, discount rate and consumer confidence variables are found significant. While non-human wealth held affects life insurance consumption in negative way, wages and discount rate affect in positive way.

Anderson and Nevin [8] investigated life insurance purchasing behavior of young newly married couples by conducting survey of young married couples for the period of 1968-1971. They use twenty independent variables and three different dependent variables (life premium expenditures, amount of life insurance purchased, type of life insurance purchased). They find that following six independent variables are statistically significant in explaining the amount of life insurance purchased; education, current household income, expected household income, net worth of household, husband's insurance before marriage and wife's insurance before marriage. Three of the independent variables are significant in explaining type of life insurance purchased; net worth, wife's insurance portfolio before marriage, influence of insurance agent.

Burnett and Palmer [9] analyzed the impact of demographic and psychographic variables on demand for life insurance. They observe that in psychographic variables work ethic, fatalism, socialization preference, religion salience, and assertiveness are the most important factors that affect life insurance consumption. In addition, education, number of children and income are the best demographic factors.

Truett and Truett (1990) compared the demand for life insurance in Mexico with that in the United States by applying time series regression. As a result, they find that age, education and level of income are the significant factors positively related with life insurance consumption. In addition, they stress that income elasticity of demand for life insurance is much higher in Mexico [10]

Çelik and Kayali [2], investigated the determinants of demand for life insurance in cross section of 31 European countries. As a result, they find that income is the central variable which affects life insurance consumption. In addition, while the impact of population and income on demand for life insurance is positive, education level and inflation affect life insurance consumption in negative way $[11,12]$.

\section{Model Specification}

This study adopts logistic regression modeling technique. The choice of this methodology stems from the fact that the regressand of the model is binary. The logistic regression is specified as

$\ln \left[\mathrm{P}_{\mathrm{i}} /\left(1-\mathrm{P}_{\mathrm{i}}\right)\right]=\lambda_{0}+\chi_{1} \mathrm{~A}+\chi_{2} \mathrm{Y}+\chi_{3} \mathrm{E}+\lambda_{4} \mathrm{~T}+\lambda_{5} \mathrm{D}+\lambda_{6} \mathrm{O}_{1}+\chi_{7} \mathrm{O}_{2}+\lambda_{8} \mathrm{O}_{3}+$ $\chi_{9} \mathrm{G}+\chi_{10} \mathrm{I}+\mu$

Where:

$\mathrm{A}=$ age of respondent

$\mathrm{Y}=$ Average monthly income of respondent.

$\mathrm{E}=$ Education of respondent $\{\mathrm{E}=1$ if has at least SHS education equivalence, $\mathrm{E}=0$ if has at most JHS education equivalence

$\mathrm{T}=$ Type of employment $\{\mathrm{T}=1$ if self-employed and $\mathrm{T}=0$ if otherwise $\}$

$\mathrm{D}=$ Number of dependents of respondents

$\mathrm{O}_{\mathrm{i}}=$ Opinion on insurance firm $(\mathrm{s})\{\mathrm{O}=1$ if Excellent, $\mathrm{O}=2$ if Very $\operatorname{good} \mathrm{O}=3$ if good, and $\mathrm{O}=4$ if bad\}.

$\mathrm{G}=\mathrm{Gender}$ of respondent $\{\mathrm{G}=1$ if Male, $\mathrm{G}=0$ if otherwise $\}$

$\mathrm{I}=\mathrm{An}$ idea on what insurance is $\{\mathrm{I}=1$ if yes and $\mathrm{I}=0$ if no $\}$

$\mu=$ Error term

$\lambda_{0}, \lambda_{1} \ldots \ldots . . . \lambda_{10}=$ The parameters to be estimated.

$\left[\mathrm{P}_{\mathrm{i}} /\left(1-\mathrm{P}_{\mathrm{i}}\right)\right]=$ The Odds of taking Life Insurance.

\section{Data and Sampling}

The study relied purely on cross sectional and primary data collected from 256 inhabitants chosen through simple random sampling from the Ayeduase-Kumasi community. The Data was obtained through questionnaires.

\section{Results and Discussion}

\section{Descriptive analyses}

The descriptive statistics of the study are shown in Table 1a. Table $1 \mathrm{a}$ also indicates that there are 256 observations. The Age of respondents is wide spread with a minimum age of 19 years and a maximum of 79 years. This gives average age of respondents to be approximately 38 years. Income had the biggest spread with the minimum of Gh\$200 and a maximum of $\mathrm{Gh} \$ 2000$.The average income of respondents stood at Gh\$939.95. Table 1a also shows that the number of dependents per 


\begin{tabular}{|l|c|c|c|c|c|}
\hline & N & Minimum & Maximum & Mean & Std. Deviation \\
\hline Age & 256 & 19.00 & 79.00 & 37.5391 & 10.77827 \\
\hline Income & 256 & 200.00 & 2000.00 & 939.952 & 286.01742 \\
\hline $\begin{array}{l}\text { Number of } \\
\text { Dependants }\end{array}$ & 256 & .00 & 12.00 & 3.6250 & 2.63014 \\
\hline
\end{tabular}

Source: Authors' construction, 2014.

Table 1a: Descriptive statistics for continuous variables ( $\mathrm{N}=$ Observations)

\begin{tabular}{|l|l|c|c|c|c|}
\hline & & \multirow{2}{*}{ Frequency } & \multicolumn{3}{|c|}{ Parameter coding } \\
\hline & & & $\mathbf{1}$ & $\mathbf{( 2 )}$ & $\mathbf{( 3 )}$ \\
\hline \multirow{2}{*}{$\begin{array}{l}\text { Opinion About } \\
\text { Insurance Firms }\end{array}$} & excellent & 4 & 1 & 0 & 0 \\
\hline & very good & 19 & 0 & 1 & 0 \\
\hline & Good & 124 & 0 & 0 & 1 \\
\hline & Bad & 109 & 0 & 0 & 0 \\
\hline Idea on Insurance & No & 12 & 1 & & \\
\hline Education Level & Yes & 244 & 0 & & \\
\hline Type of Employment & at most JHS & 56 & 1 & & \\
\cline { 2 - 6 } & at least SHS & 200 & 0 & & \\
\hline & employed by & 202 & 1 & & \\
\hline other & Self employed & 54 & 0 & & \\
\hline Gender & Female & 73 & 1 & & \\
\hline & Male & 183 & 0 & & \\
\hline
\end{tabular}

Source: Authors' construction, 2014.

Table 1b: Descriptive statistics of categorical variables.

\begin{tabular}{|l|l|c|c|c|}
\hline \multirow{3}{*}{ Variables } & & Score & Df & Sig. \\
\cline { 2 - 4 } & Age & 0.001 & 1 & 0.977 \\
\cline { 2 - 5 } & Income & 4.396 & 1 & 0.036 \\
\hline & Gumber of Dependants & 3.650 & 1 & 0.056 \\
\hline & Education Level & 0.259 & 1 & 0.610 \\
\hline & Type of Employment & 0.349 & 1 & 0.555 \\
\hline Idea on Insurance & 0.590 & 1 & 0.442 \\
\hline Opinion & 9.002 & 3 & 0.029 \\
\cline { 2 - 5 } & Excellent & 7.244 & 1 & 0.007 \\
\hline & Very good & 0.825 & 1 & 0.364 \\
\hline & Good & 0.803 & 1 & 0.370 \\
\hline Overall Statistics & 26.341 & 10 & 0.003 \\
\hline
\end{tabular}

Source: Authors' construction, 2014

Table 1c: Contribution of Variables to model fit.

each respondent stood at approximately four (4) dependents.

Table $1 \mathrm{~b}$ indicates that seventy-three (73) of the respondents are females and one hundred and eighty three (183) respondents are males. Out of total respondents of 256, fifty-four (54) were self-employed and two hundred and two (202) being employed by someone else. The "someone else" here could be the government or a private entrepreneur. The table also shows that two hundred (200) of respondents have at least Senior High School (SHS) Education whiles Fifty-six (56) had at most Junior High School (JHS) Education. Two hundred and Fortyfour (244) had idea on what insurance is about whiles twelve (12) indicated ignorance of insurance. Four (4) respondents rated insurance firms as providing excellent services, nineteen (19) indicated very good services; one hundred and twenty-four (124) tagged insurance firms as providing good services and one hundred and nine (109) indicated that insurance firms' services are bad. This in fact, tells that the people have low confidence in the insurance firms $[13,14]$.

\section{Logistic regression results}

The Table 1c indicates that almost all variables in the model contributed to the explanation of the Odds of taking insurance. Average monthly Income, Number of dependents and opinion contributed at significance of less than $0.036,0.056$ and 0.029 respectively with one (1) degree of freedom for income and number of dependents whiles opinion has 3 degrees of freedom. Even though Gender, Education Level, Type of employment, and Age contributed to the model fit, they were not significant. The test for overall model significance is shown in Table 1c.

The Table $1 \mathrm{~d}$ shows that the Chi-Square is statistically significant at less than 0.001 with 10 degrees of freedom. Average monthly Income had a positive impact on the odds of taking life insurance. It adds 0.001 to odds of taking insurance and statistically significant at 0.10 level. That is when income is high people are able to afford the cost of taking insurance. The table shows that a male adds 0.458 to the odds of taking life insurance more than females. This suggests that males are more likely to take life insurance. The coefficient of Gender (male) was not statistically significant. Persons with at least SHS education are more likely to take life insurance policy than persons with at most JHS education. From Table le persons with at least SHS education add 0.658 to the odds of taking life insurance than persons with at most JHS education. Persons employed by others also add 0.821 to the odds of taking life insurance than self-employed persons. This variable was statistically significant at 0.05 level. Age had negative relationship with the odds of taking life insurance. That is from the Table 1e, age reduces the odds of taking life insurance by -0.044 . That is as age increases persons are more likely not to take life insurance. The age variable was statistically significant at 0.05 level. Number of dependents influenced the odds of taking insurance positively. It had a positive influence of 0.213 on the odds of taking life insurance. Table 1e also indicates that if persons have idea about what insurance is then they are more likely to take life insurance. That is those with idea on insurance add 0.379 to the odds of taking life insurance than those without idea on insurance. Table 1e moreover shows that the opinion people can

\begin{tabular}{|l|l|c|c|c|}
\hline & & Chi-square & df & Sig. \\
\hline Step 1 & Step & 28.642 & 10 & 0.001 \\
\hline & Block & 28.642 & 10 & 0.001 \\
\hline & Model & 28.642 & 10 & 0.001 \\
\hline
\end{tabular}

-2 Log likelihood (305.7236751713324).

Source: Authors' construction, 2014.

Table 1d: Omnibus tests of model coefficients.

\begin{tabular}{|l|c|c|c|c|c|c|}
\hline & B & S.E. & Wald & df & Sig. & Exp(B) \\
\hline Age & -0.044 & 0.019 & 5.576 & 1 & $0.018^{* * *}$ & 0.957 \\
\hline Income & 0.001 & 0.001 & 2.818 & 1 & $0.093^{* *}$ & 1.001 \\
\hline $\begin{array}{l}\text { Number of } \\
\text { Dependants }\end{array}$ & 0.213 & 0.075 & 8.138 & 1 & $0.004^{*}$ & 1.237 \\
\hline Gender & 0.458 & 0.317 & 2.091 & 1 & 0.148 & 1.581 \\
\hline Education Level & 0.658 & 0.361 & 3.311 & 1 & $0.069^{* * *}$ & 1.930 \\
\hline Type of Employment & 0.821 & 0.385 & 4.552 & 1 & $0.033^{* *}$ & 2.273 \\
\hline Idea of Insurance & 0.379 & 0.693 & 0.300 & 1 & 0.584 & 1.461 \\
\hline Opinion & & & 1.841 & 3 & 0.606 & \\
\hline Excellent & 23.582 & $1.895 \mathrm{E} 4$ & 0.000 & 1 & 0.999 & $1.743 \mathrm{E} 10$ \\
\hline Very good & -0.052 & 0.586 & 0.008 & 1 & 0.929 & 0.949 \\
\hline Good & 0.381 & 0.302 & 1.591 & 1 & 0.207 & 1.463 \\
\hline Constant & -1.766 & 0.794 & 4.954 & 1 & $0.026^{* *}$ & 0.171 \\
\hline
\end{tabular}

$B=$ Coefficients of logistic regression; SE: Standard Error; df: Degrees of Freedom Sig: Significance level $\operatorname{Exp}(B)=$ odds ratio of taking insurance. ( ${ }^{*}$ significant at $1 \%$ ) ${ }^{* *}$ significant at $\left.5 \%\right)\left({ }^{* * *}\right.$ significant at $\left.10 \%\right)$.

Source: Authors' construction, 2014.

Table 1e: Logistic regression coefficients. 
Citation: Sarkodie EE, Yusif HM (2015) Determinants of Life Insurance Demand, Consumer Perspective - A Case Study of Ayeduase-Kumasi Community, Ghana. Bus Eco J 6: 170. doi:10.4172/2151-6219.1000170

affect their decision of taking or not taking life insurance. Those who perceive insurance firms to be of better standing are more likely to take life insurance than otherwise, though this variable was not statistically significant.

\section{Implications of the study}

The study implied that insurance firms should reduce premium to attract aged customers. Also, market segmentation could help insurance firms to maximize their premium charges. Moreover, insurance firms must be proactive in dealing with customers since the perception of customers hugely influences the chances of taking insurance.

\section{Summary and Conclusion}

The determinants of life insurance were investigated in this study. This study had similar results to previous studies and deviates as well. Çelik and Kayali [2] found a positive relationship between income and odds of taking insurance and that was not different from the results of this study. Contrary to Çelik and Kayali [2] higher education influences positively the odds of taking life insurance. Life insurance demand also increases if people have better perception about insurance firms. Age had a negative relationship with the odds of taking life insurance whiles number of dependents had positive relationship with the odd of taking insurance.

It is recommended that insurance firms take into consideration variables such as income, age, and type of employment in determining premium to be paid and not only the degree of risk exposure the individual has, though that has been the theoretical basis for determining premium as shown in "Advanced Microeconomic Theory by Jehle and Reny". These variables as could be observed from the results hugely determine whether an individual could take life insurance. Moreover, segmenting customers into different groups by using the type of employment as basis of segmentation could help insurance firms to prescribe policies that customers may patronize.

\section{References}

1. Nesterova D (2008) Determinants of The Demand For Life Insurance: Evidence
From Selected CIS And CEE Countries. A thesis submitted in partial fulfillment of the requirements for the degree of Master of Arts in Economics, National University Kyiv-Mohyla Academy Master's Program in Economics.

2. Celik S, Kayali MM (2009) Determinants of demand for life insurance in European countries. Problems and Perspectives in Management, p. 7.

3. Beck T, Webb I (2003) Economic, Demographic and Institutional Determinants of Life Insurance Consumption across Countries. The World Bank Economic Review 17: 51-88.

4. Hammond JP, Houston DB, Melander ER (1967) Determinants of Household Life Insurance Premium Expenditures: An Empirical Investigation. The Journal of Risk and Insurance 34: 397-408.

5. Neumann S (1969) Inflation and Saving through Life Insurance. The Journal of Risk and Insurance 36: 567-582.

6. Berekson LL (1972) Birth Order, Anxiety, Affiliation and the Purchase of Life Insurance. The Journal of Risk and Insurance 39: 93-108.

7. Fortune P (1973) A Theory of Optimal Life Insurance: Development and Test. The Journal of Finance 28: 587-600

8. Anderson DR, Nevin JR (1975) Determinants of Young Marrieds' Life Insurance Purchasing Behavior: An Empirical Investigation. The Journal of Risk and Insurance 42: 375-387.

9. Burnett JJ, Palmer BA (1984) Examining Life Insurance Ownership through Demographic and Psychographic Characteristics. The Journal of Risk and Insurance, 51: 453-467.

10. Babbel DF (1981) Inflation, Indexation, and Life Insurance Sales in Brazil. The Journal of Risk and Insurance 48: 111-135.

11. Browne MJ, Kim K (1993) An International Analysis of Life Insurance Demand The Journal of Risk and Insurance 60: 616-634.

12. Hwang T, Greenford B (2005) A Cross-Section Analysis of The Determinants of Life Insurance Consumption in Mainland China, Hong Kong, and Taiwan. Risk Management and Insurance Review 8: 103-125.

13. Li D, Moshirian F, Nguyen P, Wee T (2007) The Demand for Life Insurance in OECD Countries. The Journal of Risk and Insurance 74: 637-652.

14. Mantis G, Farmer R (1968) Demand for Life Insurance. The Journal of Risk and Insurance 35: 247-256 